\title{
A Tridimensional Model of Proangiogenic Calcium Signals in Endothelial Cells
}

\author{
Luca Munaron*
}

\author{
Department of Animal and Human Biology, Centre for Nanostructured Interfaces and Surfaces (NIS), Centre for \\ Complex Systems in Molecular Biology and Medicine (SysBioM), and CNISM, University of Torino, Italy
}

\begin{abstract}
Angiogenic factors, including bFGF and VEGF, induce cytosolic calcium $\left(\mathrm{Ca}_{\mathrm{c}}\right)$ increases in endothelial cells, critically involved in angiogenesis progression. At low agonist concentrations, $\mathrm{Ca}_{\mathrm{c}}$ elevation is mainly due to calcium entry controlled by a complex interplay between two intracellular messengers, arachidonic acid (AA) and nitric oxide (NO), released upon stimulation with proangiogenic factors: they trigger spatially localized calcium signals restricted to the cell periphery, and such a spatiotemporal pattern could contribute to the specificity of cellular responses.

Based on experimental measurements, here we provide the first quantitative spatiotemporal 3D modeling of proangiogenic calcium events in endothelial cells using Virtual Cell framework. The main aims were to validate previously proposed signaling pathways and to suggest new experimental protocols.

The most relevant conclusions are: 1. The interplay between AA and NO, previously proposed to be responsible for VEGF/bFGF-dependent calcium entry in endothelial cells, triggers peripheral calcium signals that reproduce the experimental measurements; 2. Spatial restriction is not an artefact due to the calcium-sensitive dye; 3 . Channels clusterization in thin lamellipodia plays a key role in the generation of the peripheral-restricted proangiogenic calcium signals; 4. A model containing two distinct channels, named AAAC and NOAC, respectively activated by AA or NO, explains the basic properties of proangiogenic calcium signals.

This could be considered an 'open model' containing the simplest conditions leading to a satisfactory reproduction of the experimental results: it should be implemented in order to make it more complete and to maximize physical and biochemical constraints.
\end{abstract}

Keywords: Intracellular calcium, endothelial cell, angiogenesis, modeling.

\section{INTRODUCTION}

In the last years several authors reported the existence of local calcium signals in virtually all cell types $[1,2]$.

Calcium 'microdomains' are classified on the basis of their different spatial restriction, time course and amplitude and are related to specific intracellular molecular machineries: for this reason they contribute to the specificity of the cellular response $[1,3,4]$.

In calf pulmonary artery endothelial cells (CPAEs), elementary events precede the onset of the massive ATPinduced $\mathrm{Ca}^{2+}$ release from intracellular stores, leading to the vasoactive response $[5,6]$.

Elementary events can also be due to calcium entry from the extracellular medium: in neurons, exocytotic release of synaptic vesicles is controlled by subplasmamembrane calcium microdomains triggered by the opening of voltage operated channels (VOCs) [7, 8]; calcium microdomains with a subplasmalemmal localization are detectable in

*Address correspondence to this author at the Department of Animal and Human Biology, University of Torino, Via Accademia Albertina 13, 10123 Torino, Italy; Tel: +39.011.6704667; Fax: +39.011.6704508; E-mail: luca.munaron@unito.it stimulated and unstimulated smooth muscle cells $[9,10]$. In endothelial cells (ECs), channels associated with the caveolae give rise to rather inhomogeneous high calcium levels along the subplasmamembrane cytoplasmic ring that selectively regulates nitric oxide $(\mathrm{NO})$ release $[11,12]$.

In recent years we provided evidence for the critical role of calcium signaling in the control of endothelial cell proliferation and angiogenesis [13-16]. In bovine aortic endothelial cells (BAECs) we described the biophysical properties of calcium channels activated by proangiogenic peptides including bFGF, IGF and VEGF: such channels are modulated by the interplay of two intracellular messengers, arachidonic acid (AA) and nitric oxide (NO), both released by ECs after proangiogenic stimulation [17]. The signal transduction pathways involved in this process are quite complex and probably more than one type of calcium channel is involved [16-18].

Interestingly, stimulation of BAECs with AA or $\mathrm{NO}$ at low concentrations triggers peripheral and localized calcium signals [19]. They decay in space and are usually unable to propagate into the perinuclear and nuclear regions: a very similar response was observed after stimulation with proangiogenic peptides, such as bFGF and VEGF, able to trigger the intracellular release of $\mathrm{AA}$ and $\mathrm{NO}$ [19]. We suggested that the peculiar spatiotemporal dynamics of 
mitogen-activated cytosolic calcium events in ECs could lead to the involvement of differential patterns of calciumdependent proteins and genes during the multistepped physiopathological process of angiogenesis [19].

The interplay among several factors could contribute to the generation of calcium microdomains. Firstly, the highly variable 3D geometry of the cells in culture (shape, Surface/Volume ratio of peripheral processes and centralnuclear regions) could account for the preferential peripheral localization: non confluent BAECs in monolayer display quite variable dimensions and the peripheral processes (lamellipodia and phylopodia) are very thin compared to the central-nuclear region [19]. Several authors have discussed the role of 3D cell structure experimentally and theoretically: however, the interest is usually focused on calcium release from intracellular stores rather than on calcium entry from extracellular medium $[5,20]$. Secondly, the distribution and properties of calcium 'buffers' (proteins, mitochondria) changes from cell to cell and may contribute to the spatial restriction [21, 22]. Finally, several evidences suggest the existence of lipidic rafts or caveolae and supermolecular complexes called signalplexes (or signallsomes) in virtually all cell types including ECs: interestingly, many molecules involved in calcium homeostasis and signaling are included in caveolae [23-26].

Here we used Virtual Cell software, already successfully applied by other authors to model cellular processes [27-29], to provide the first realistic three-dimensional (3D) model accounting for proangiogenic calcium signals in BAECs: it is based on endothelial-specific morphological and functional parameters, most of which experimentally measured in the same cell type.

Simulation reproduces the proangiogenic localized calcium signals experimentally described supporting in a quantitative way the signal transduction pathway proposed in previous papers; moreover it allows to suggest the critical role for channel clusterization in thin lamellipodia, typical of ECs geometry. Finally, we investigated the complex and not entirely known interplay between $\mathrm{AA}$ and $\mathrm{NO}$ in the activation of proangiogenic calcium channels [17], testing the potential involvement of two distinct AA- and NOactivated channels: further experimental data, in particular the identification of AA- and NO-operated calcium channels, still unknown, and their cellular localization, will be requested to validate this model.

\section{METHODS}

\section{D Structure of the Cell}

Spatial 3D geometries have been obtained by real cultured bovine aortic endothelial cells (BAECs) imaged using confocal microscopy.

\section{Model Construction}

The Virtual Cell software environment (available at: http://www.nrcam.uchc.edu) was used to develop 3D spatial model. The mathematical details of the model are provided in the results (see Tables $\mathbf{1}, \mathbf{2}$ ).

\section{RESULTS}

Mathematical Model for Proangiogenic-Induced StoreIndependent Calcium Entry in BAECs

\section{General Model Description}

In all cell types cytosolic calcium levels are determined by a balance of entry, efflux or extrusion from the cytosol, and buffering [8]: the calcium dynamics is governed by the partial differential equation $[30,31]$.

$\frac{\partial C a_{c}}{\partial t}=D \nabla^{2} C a_{c}+\left(J_{\text {entry }}-J_{\text {extrusion }}\right)+J_{\text {buffering }}$

The first term in equation 1 is due to $\mathrm{Ca}^{2+}$ diffusion, in which $\mathrm{D}$ is the diffusion coefficient of free cytosolic calcium $\left(\mathrm{Ca}_{\mathrm{c}}\right) . J_{\text {entry }}$ and $J_{\text {extrusion }}$ are respectively the rates of change of $\left[\mathrm{Ca}_{\mathrm{c}}\right]$ due to the opening of calcium channels and activation of pumps and exchangers. $J_{\text {buffering }}$ is the rate of change of $\left[\mathrm{Ca}_{\mathrm{c}}\right]$ due to buffering. The initial $\mathrm{Ca}_{\mathrm{c}}$ distribution is assumed uniform.

Entry mechanisms involve plasmamembrane and/or ER calcium-permeable channels and the related fluxes are passive following electrochemical driving force. In our particular case, we have previously shown in BAECs that low concentrations of arachidonic acid (AA) and nitric oxide (NO) do not activate release from intracellular stores and the following store-dependent calcium entry (SOCE): therefore we can consider the store-independent calcium entry (NSOCE) from extracellular medium as the only relevant mode for increasing $\mathrm{Ca}_{\mathrm{c}}$ [17-19]. Equation 1 can be written as:

$\frac{\partial C a_{c}}{\partial t}=D \nabla^{2} C a_{c}+\left(J_{N S O C E}-J_{\text {extrusion }}\right)+J_{\text {buffering }}$

On the other hand cytosolic $\mathrm{Ca}_{\mathrm{c}}$ can be extruded from the cytosol via plasmamembrane and ER ATPases (respectively $P M C A$ and SERCA) and Na-Ca exchangers (NCX). In ECs each active extrusion mechanism plays a specific role during different types of calcium signals and is regulated by multiple mechanisms [32]. Endothelial SERCAs are typically involved in the recovery of calcium response after agonist removal [33]: thus, being the recovery phase of proangiogenic calcium signals above the aim of this work, we did not consider its role in our model (equation 3 ).

$\frac{\partial C a_{c}}{\partial t}=D \nabla^{2} C a_{c}+\left(J_{N S O C E}-J_{P M C A}-J_{N C X}\right)+J_{\text {buffering }}$

The general scheme of our 3D spatial biomodel is shown in Fig. (1), including chemical species and reactions described in the previous section (Fig. 1A) and geometries (Fig. 1B).

Following Mottola et al. (2005), NO release is under a double regulation by both $\mathrm{AA}$ and $\mathrm{Ca}_{\mathrm{c}}$. Calcium channels (AA-activated channel, AAAC, and NO-activated channel, NOAC, see below), pumps and exchangers are in a fixed number, restricted in the plasmamembrane compartment (distributed or clusterized as indicated in the following section). Endogenous and exogenous calcium buffers are included in the cytosolic and nuclear compartment. Diffusion of calcium across the nuclear envelope was taken as 

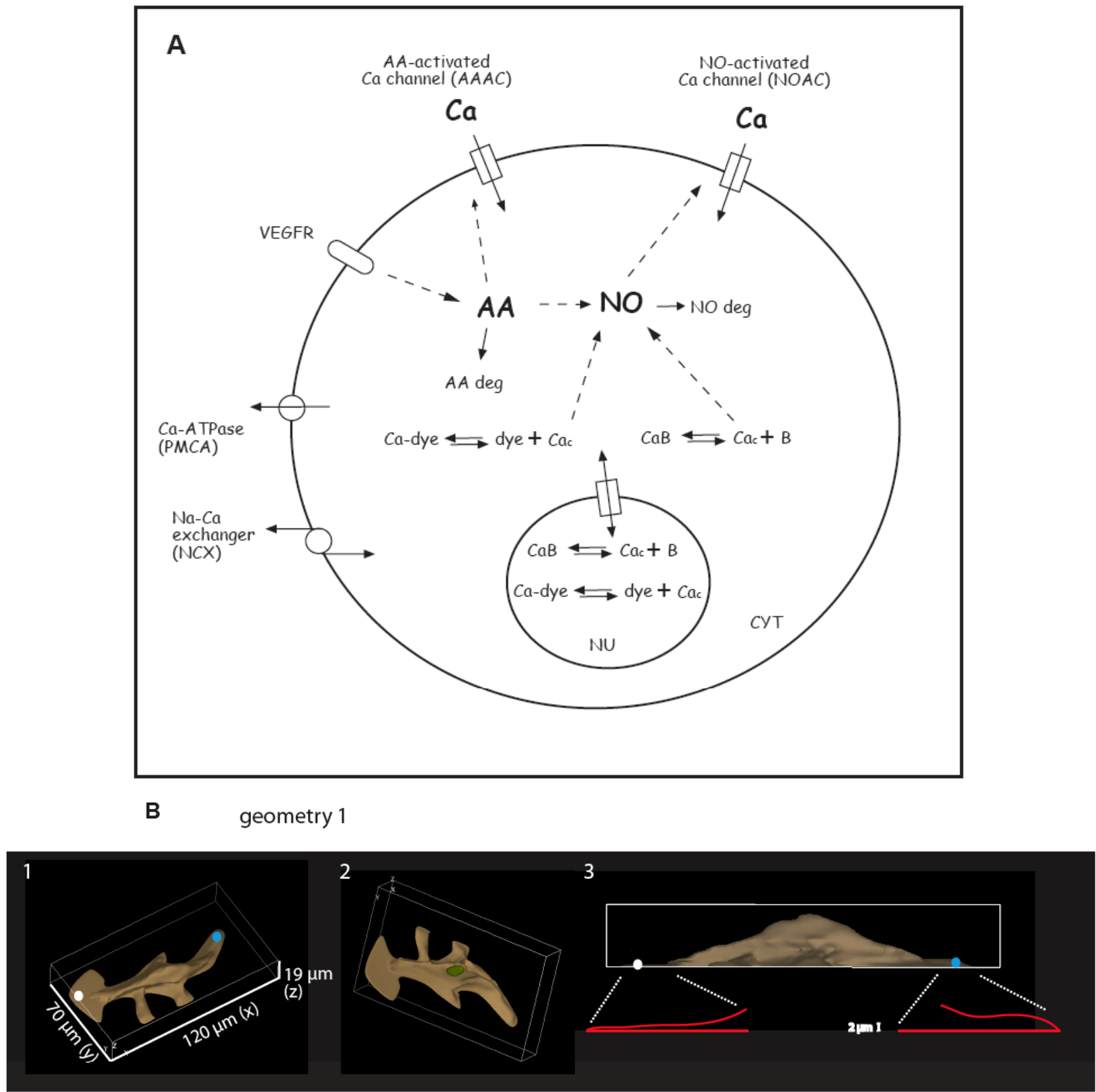

C

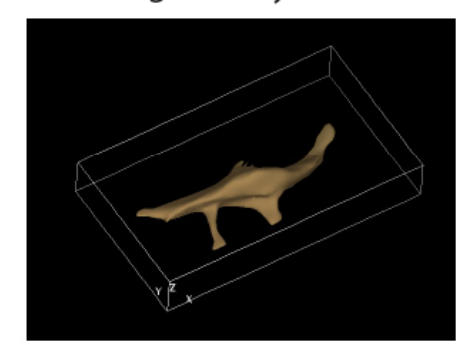

Fig. (1). A. Scheme of the model including the main components. Dashed arrows stand for indirect or not completely known pathways. Abbreviations: AA deg and NO deg: AA and NO degradation into metabolites; CYT: cytosol; NU: nucleus. B, C. Two different endothelial cell geometries ( $\mathrm{g} 1$ and g2). Geometry $\mathbf{1}$ is a large cell with thin lamellipodia. Geometry $\mathbf{2}$ is the same cell without any lamellipodia. B. Three views of g1 cell. Panel 1: from the top; panel 2: from the bottom (nucleus in green); panel 3: enlarged side view. White and blue circles in panels 1 and 3 are correspondent regions. C. Top view of g2 cell. Shapes are taken from 3D confocal reconstruction of real BAECs.

occurring through non-selective nuclear pores, such that the permeability was proportional to diffusion constant of the ion in the cytosol [34].
Partial differential equations (PDEs) are solved by Virtual cell simulator (for details see Virtual cell web site). 
We decomposed the 3D computational domain (x-y-z: $120,70,19 \mu \mathrm{m})$ into 1200000 elements and ran simulations using a 1-s time step.

\section{Geometry}

In order to provide a 3D-spatially-resolved simulation of the cytosolic calcium signals following AA-activated calcium entry described in previous papers, and in particular in Tomatis et al. (2007), we have to consider the effect of cell shape and dimensions in the model: indeed ECs growing on monolayer show a wide distribution in areas, perimeters and protrusion extensions, as quantitatively reported [19].

We decided to consider 2 main ECs types, according to the most usual shapes (morphologies) observed in culture (Figs. 1B,C).

Geometry $\mathbf{1}$ is a large cell with a central region containing the nucleus and long thin peripheral regions (lamellipodia) mostly in the left side (Fig. 1B). Geometry 2 is the same cell without any thin peripheral regions (Fig. 1C).

A

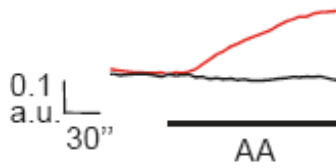

C

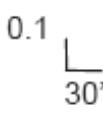

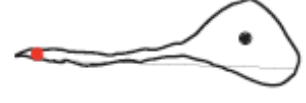

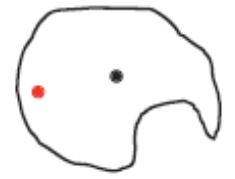

Properties of Calcium Entry Activated by Proangiogenic Factors on BAECs

Confocal microscopy on cells loaded with calcium green1 probe allowed us to identify and describe $\mathrm{Ca}_{\mathrm{c}}$ peripheral increases activated by proangiogenic factors (Fig. 2A-D; for more details, see [19]).

\section{AA-Activated Channel (AAAC)}

General biophysical properties of calcium-permeable currents activated by proangiogenic peptides (bFGF, IGF, VEGF) and intracellular messengers (AA and NO) have been obtained by patch clamp technique in whole cell and inside out configuration $[18,35]$. The simulated current was designed to fit the most relevant and conserved parameters shown in Table $\mathbf{1}$.

AA-activated calcium current (similarly to bFGF activated current) in BAECs using whole cell and single channel configurations is characterized by an activation phase reaching a peak and by a following desensitization phase in the presence of the agonist (a representative trace in Fig.

B

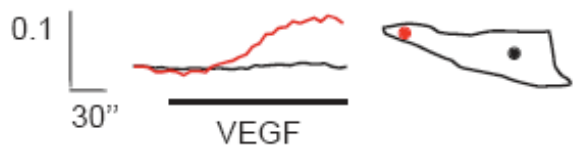

D

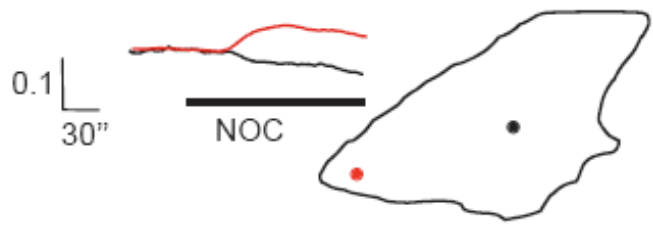

Fig. (2). Confocal calcium measurements with calcium green-1.

A-D. Calcium microdomains measured after stimulation of BAECs with $5 \mu \mathrm{M} \mathrm{AA}, 50 \mathrm{ng} / \mathrm{ml} \mathrm{VEGF,} 20 \mathrm{ng} / \mathrm{ml} \mathrm{bFGF}$, or $1 \mathrm{mM}$ NOC-18 (NO donor). Red and black traces correspond respectively to peripheral and central ROIs (respectively red and black circles in the cell shape).

Table 1. Properties of Currents and Calcium Signals Activated by Proangiogenic Factors in BAECs Respectively Using Patch Clamp (Whole Cell and Single Cell Configurations, Voltage Clamp Mode) and Single Cell Fluorimetric Techniques (for Details see [17-19, 35]). nd Stands for Not Experimentally Determined. $E_{r e v}$ is the Reversal Potential of the AgonistActivated Current

\begin{tabular}{|c|c|c|c|c|c|c|c|}
\hline Agonist & $\begin{array}{c}\text { Peak Current Density } \\
\text { Amplitude (pA/pF) }\end{array}$ & $\begin{array}{l}\mathbf{E}_{\text {rev }} \\
(\mathrm{mV})\end{array}$ & Permeability & Desensitization & $\begin{array}{l}\text { Time to Peak } \\
\text { for } \mathrm{Ca}_{\mathrm{c}}(\mathrm{s})\end{array}$ & $\begin{array}{l}\text { Time to Peak for } \\
\text { Current (s) }\end{array}$ & $\begin{array}{l}\text { Microdomain } \\
\text { Detection }\end{array}$ \\
\hline bFGF & $3.1 \pm 2.8$ & $8.1 \pm 12.5$ & $\mathrm{Na}, \mathrm{Ca}, \mathrm{K}$ & Yes & $20-120$ & $15-180$ & Yes \\
\hline IGF & $4.5 \pm 2.4$ & $6.7 \pm 7.4$ & $\mathrm{Na}, \mathrm{Ca}, \mathrm{K}$ & Yes & $20-120$ & $30-115$ & nd \\
\hline VEGF & nd & $\approx 0$ & $\mathrm{Na}, \mathrm{Ca}, \mathrm{K}$ & Yes & $20-120$ & nd & Yes \\
\hline $\mathrm{AA}$ & $3.0 \pm 2.7$ & $-5 \pm 17$ & $\mathrm{Na}, \mathrm{Ca}, \mathrm{K}$ & Yes & $20-120$ & $10-150$ & Yes \\
\hline
\end{tabular}


3A): the following equation fits the kinetic properties of the whole cell current.

$$
I_{A A A C}=G_{A A A C} *\left(\frac{R T}{2 F} \log \frac{C a_{e}}{C a_{c}}-V_{m}\right)
$$

in which,

$$
G_{\text {AAAC }}=G_{\text {max } \_ \text {AAAC }} \frac{A A}{A A+K_{A A A C}} h_{c}^{2}
$$

The corresponding simulation is shown in Fig. (3B).

A

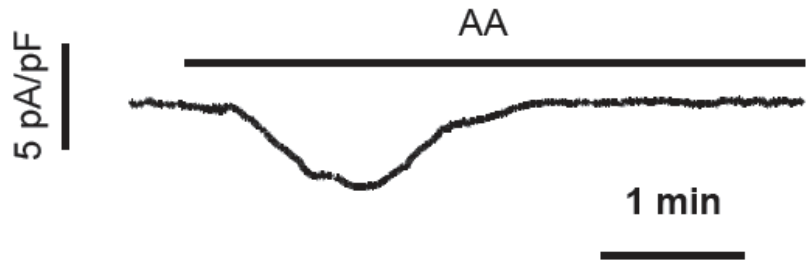

C

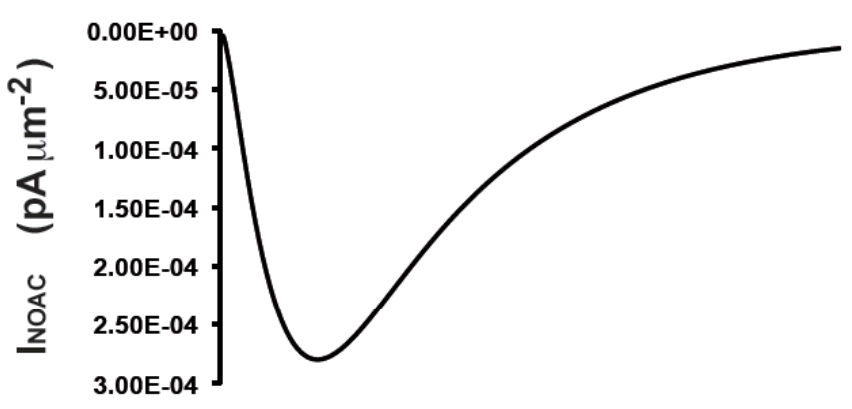

E

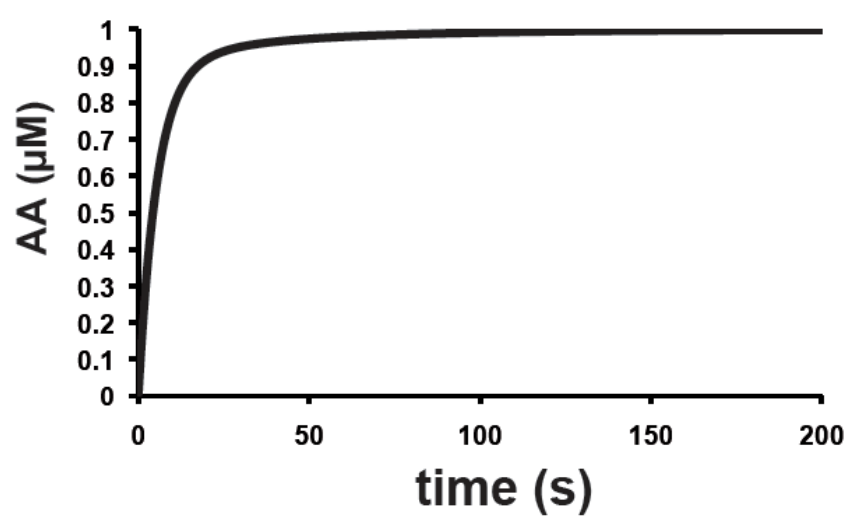

The maximal conductance $\left(\mathrm{G}_{\max \text { AAAC }}\right)$ was chosen to fit the mean peak of whole cell currents activated by AA in patch clamp experiments. Corrections have been introduced to account for the relative calcium-permeability of proangiogenic calcium channels, that are non-selective, permeable to $\mathrm{Ca}, \mathrm{Na}$ and $\mathrm{K}$ ions.

The second term in equation describes the activation kinetics of the current, dependent on AA (AA) (available for channel interaction): $\mathrm{K}_{\mathrm{AAAC}}$ is the concentration of $\mathrm{AA}$ responsible for the half maximal activation of the channel. AA levels depend on the production rate triggered by VEGFR activation, via a number of pathways involving

B

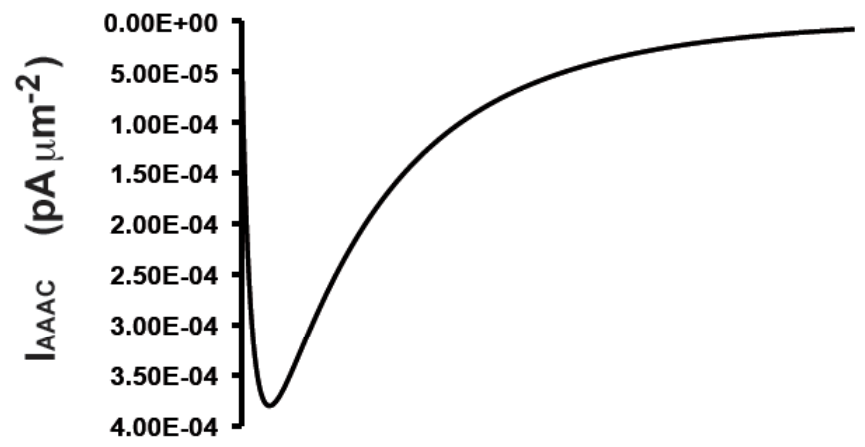

D

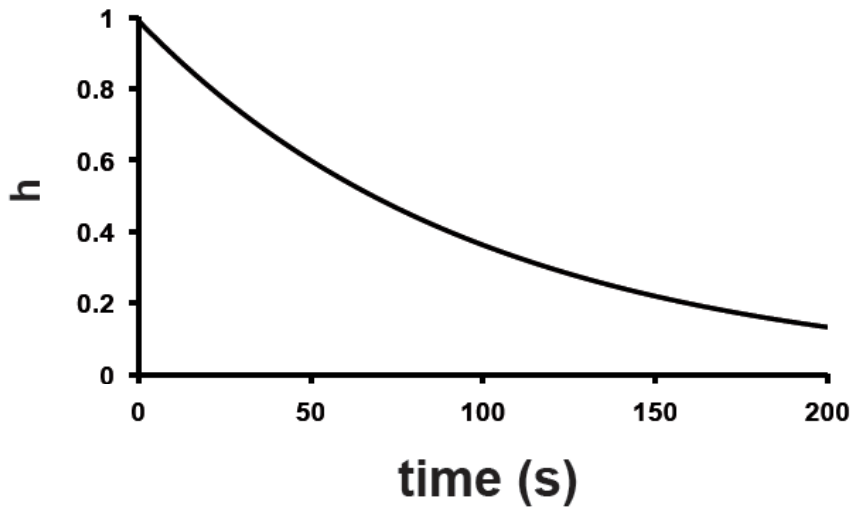

$\mathbf{F}$

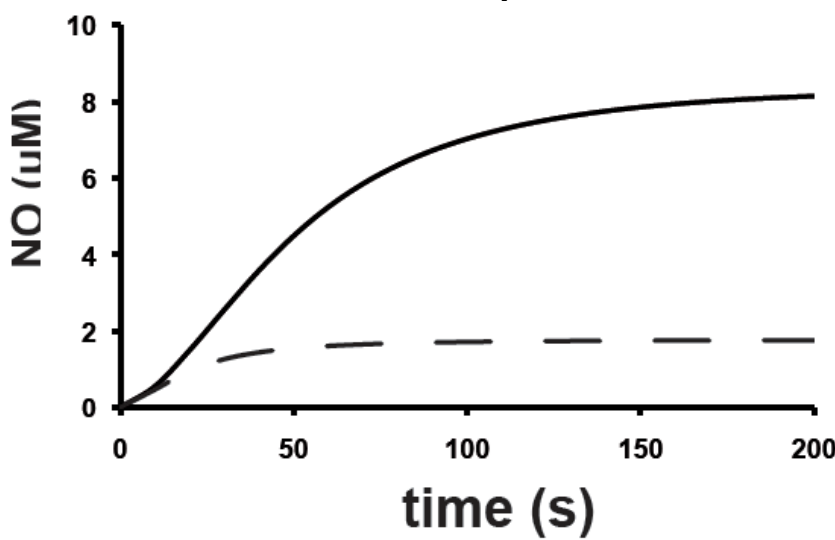

Fig. (3). A. Whole cell current measured after BAEC stimulation with $5 \mu \mathrm{M}$ AA (voltage clamp mode, $\mathrm{V}_{\mathrm{h}}=-50 \mathrm{mV}$ ). B, C. Simulation of AA-activated or NO-activated current, respectively $\mathrm{I}_{\mathrm{AAAC}}$ and $\mathrm{I}_{\mathrm{NOAC}}$. D. Time course of the probability that the channel desensitization site is not occupied (h). E. Time course of simulated AA release. F. Time course of simulated NO release. The dotted trace in Fig. (3F) is the time course of $\mathrm{NO}$ release in absence of calcium entry ( $\mathrm{I}_{\mathrm{AAAC}}$ and $\mathrm{I}_{\mathrm{NOAC}}$ excluded from simulation). 
PLA2, PLC, PLD and other enzymes (first term in equation 6), and AA degradation (second term in equation 6) by LOX, COX and CytP450 MO and the following release of eicosanoids [36]:

$J_{\text {AArel }}=\left(k f_{\text {AA_rel }}\right.$ VEGFR) $-\left(k_{\text {AA_deg }} A A\right)$

The corresponding simulation is shown in Fig. (3E). VEGFR stands for the density of active VEGF receptors in the plasmamembrane $\left(\mathrm{VEGFR}=1 \mathrm{~m}^{-2}\right.$ in all the simulations, see Tables 2, 3).

The term $h^{2}$ in equation (4) describes the current desensitisation in the presence of the fatty acid, obtained by fitting the time course of the currents experimentally measured in whole cell patch clamp experiments $[18,35]: \mathrm{h}$ is the probability that the channel desensitization site is not occupied and can be treated by a mass action equation (see simulation in Fig. 3D),

$J_{h}=k f_{h} h_{c}-k r_{h} h_{o}$

\section{Nitric Oxide-Activated Channel (NOAC)}

We have previously suggested that at least a part of AAinduced calcium entry in BAECs could be more indirect and mediated by an AA-dependent NO production [17, 19]. NO release is dependent on eNOS activation: based on the model suggested by our group in these cells [17], eNOS, in addition to the canonical calcium-dependence, can be activated by AA. To account for this double regulation, and fitting the time course of NO increase experimentally measured using fluorescent probes and selective electrodes [17, 37], we described NO production as follows (see Fig. 3F)

$$
J_{\text {NOrel }}=\frac{k_{N O r e l} \mathrm{Ca}_{c} A A}{\left(K_{N O \_C a}+C a_{c}\right)\left(K_{N O \_A A}+A A\right)}-k_{N O \_d e g} N O
$$

The first term describes NO release by eNOS: $\mathrm{k}_{\mathrm{NOrel}}$ is the maximal rate, $\mathrm{K}_{\mathrm{NO} \text { Ca }}$ and $\mathrm{K}_{\mathrm{NO} \text { AA }}$ are the dissociation constants $\left(\mathrm{K}_{\mathrm{d}}\right)$ respectively for $\mathrm{Ca}$ and AA [38, 39]. The second term accounts for NO degradation to peroxynitrites [40]. As expected, when calcium entry from AAAC and NOAC is inhibited, NO release is significantly decreased (dotted line in Fig. 3F).

In analogy with the description of AA-activated current, $\mathrm{I}_{\mathrm{NOAC}}$ (Fig. 3C) can be expressed as:

$$
I_{N O A C}=G_{\max _{-} N O A C} *\left(\frac{R T}{2 F} \log \frac{C a_{e}}{C a_{c}}-V_{m}\right)
$$

in which,

$$
G_{N O A C}=G_{\max _{-} N O A C} \frac{N O_{c}}{N O_{c}+K_{N O A C}} h_{c}^{2}
$$

\section{Calcium Efflux}

The plasmamembrane calcium ATPase (PMCA) and the $\mathrm{Na}^{+} / \mathrm{Ca}^{2+}$ exchanger mediate calcium efflux.

The rate of extrusion by the ATPase has been modeled by [41] in platelets and used for modelling ECs [42, 43]. The form of the rate equation is a sum of two Hill functions,
$J_{P M C A}=\frac{V_{b-P M C A} C a_{c}^{1.7}}{K_{b-P M C A}^{1.7}+C a_{c}^{1.7}}+\frac{V_{h i-P M C A} C a_{c}^{4.4}}{K_{h i-P M C A}^{4.4}+C a_{c}^{4.4}}$

The first term in Eq. 11 represents the capacity of the ATPase in the basal state. Upon exposure to elevated levels of cytosolic calcium, the ATPase enters an activated highcapacity mode, which is given by the second term. $\mathrm{V}_{\mathrm{b}-\mathrm{PMCA}}$, is the maximal rate of pumping of calcium in the basal state. $\mathrm{K}_{\mathrm{b}-\mathrm{PMCA}}$ is the calcium concentration at which the extrusion is half-maximal in the basal state. $\mathrm{V}_{\text {hi-PMCA }}$ and $\mathrm{K}_{\text {hi-PMCA }}$ are analogous quantities for the high-capacity term.

Valant et al. (1992) also modeled the $\mathrm{Na}^{+} / \mathrm{Ca}^{2+}$ exchanger (NCX). The form of this rate equation is that of MichaelisMenten kinetics,

$J_{N C X}=\frac{V_{N C X} C a_{c}}{K_{N C X}+C a_{c}}$

$\mathrm{V}_{\mathrm{NCX}}$ is the maximal rate of extrusion and $\mathrm{K}_{\mathrm{NCX}}$ the Michaelis-Menten constant, the calcium concentration at which the rate of exchange is half-maximal.

Finally, the total rate of calcium efflux to the extracellular space is the sum of $\mathrm{J}_{\mathrm{b}-\mathrm{PMCA}}, \mathrm{J}_{\mathrm{hi}-\mathrm{PMCA}}$ and $\mathrm{J}_{\mathrm{NCX}}$

$J=\frac{V_{b-P M C A} C a_{c}^{1.7}}{K_{b-P M C A}^{1.7}+C a_{c}^{1.7}}+\frac{V_{h i-P M C A} C a_{c}^{4.4}}{K_{h i-P M C A}^{4.4}+C a_{c}^{4.4}}+\frac{V_{N C X} C a_{c}}{K_{N C X}+C a_{c}}$

Values of $\mathrm{V}$ in each of the 3 terms have been chosen to obtain steady state condition in resting unstimulated cells (see Tables 2, 3).

\section{Calcium Buffering}

As shown before, the effective diffusion of calcium in the cytosol depends on the presence of buffers; at least two types of factors concur to the cytosolic calcium buffering: endogenous (proteins including calmodulin and others, cytoskeleton, mitochondria) and exogenous buffers, mainly the calcium-sensitive fluorescent dyes used for the measurements (dyebuffer) (according to [31]).

The rate of endogenous buffering is based on that given by several works [31, 42-47]. Dissociation constant $\left(\mathrm{K}_{\mathrm{d}}\right)$ of calcium from calmodulin ranges from 0.2 to $18 \mu \mathrm{M}$ : we used $2 \mu \mathrm{M}$ for control conditions [45]. The total concentration of calcium-binding sites $\left(\mathrm{B}_{\mathrm{TOT}}\right)$ is considered constant and has been experimentally estimated in different cell types: accordingly to Fink et al. (2000), we used $\mathrm{B}_{\text {tot }}=450 \mu \mathrm{M}$. The rate at which calcium is complexed to the buffer is proportional to the concentration of free calcium and free binding sites. Calcium also decomplexes from the protein at a rate proportional to the concentration of the complex: therefore the net rate of buffering may be described using mass-action expression as follows:

$J_{\text {buffering }}=k_{\text {buffer-on }} C a_{c} B-k_{\text {buffer-off }}(C a B)$

Please note that $\mathrm{Ca}_{\mathrm{c}} \mathrm{B}$ stands for $\left(\mathrm{Ca}_{\mathrm{c}}\right) \mathrm{x}(\mathrm{B})$ and $\mathrm{CaB}$ stands for the concentration of the complex $\mathrm{CaB}$.

The introduction of the calcium-sensitive fluorescent dye (calcium green-1 or fluo-3) for cytosolic calcium measure- 
ments affects endogenous calcium buffering systems and has to be considered. Mass action equation is,

$$
J_{\text {buffering }}=k_{\text {dyebuffer-on }} C a_{c} d y e-k_{\text {dyebuffer-off }}(\text { Cadye })
$$

Intracellular concentration of exogenous buffers $(18 \mu \mathrm{M})$,

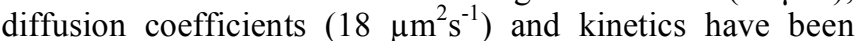
taken from previously described estimations $[31,48,49]$.
All the values used in the model and their explanations are given in Tables $\mathbf{2}, \mathbf{3}$

All the simulations are performed in conditions of receptor stimulation and $\mathrm{AA}$ release $\left(\mathrm{J}_{\mathrm{AArel}}\right.$ activated $)$, except where indicated (the last section fo the results).

Table 2. Model Constants

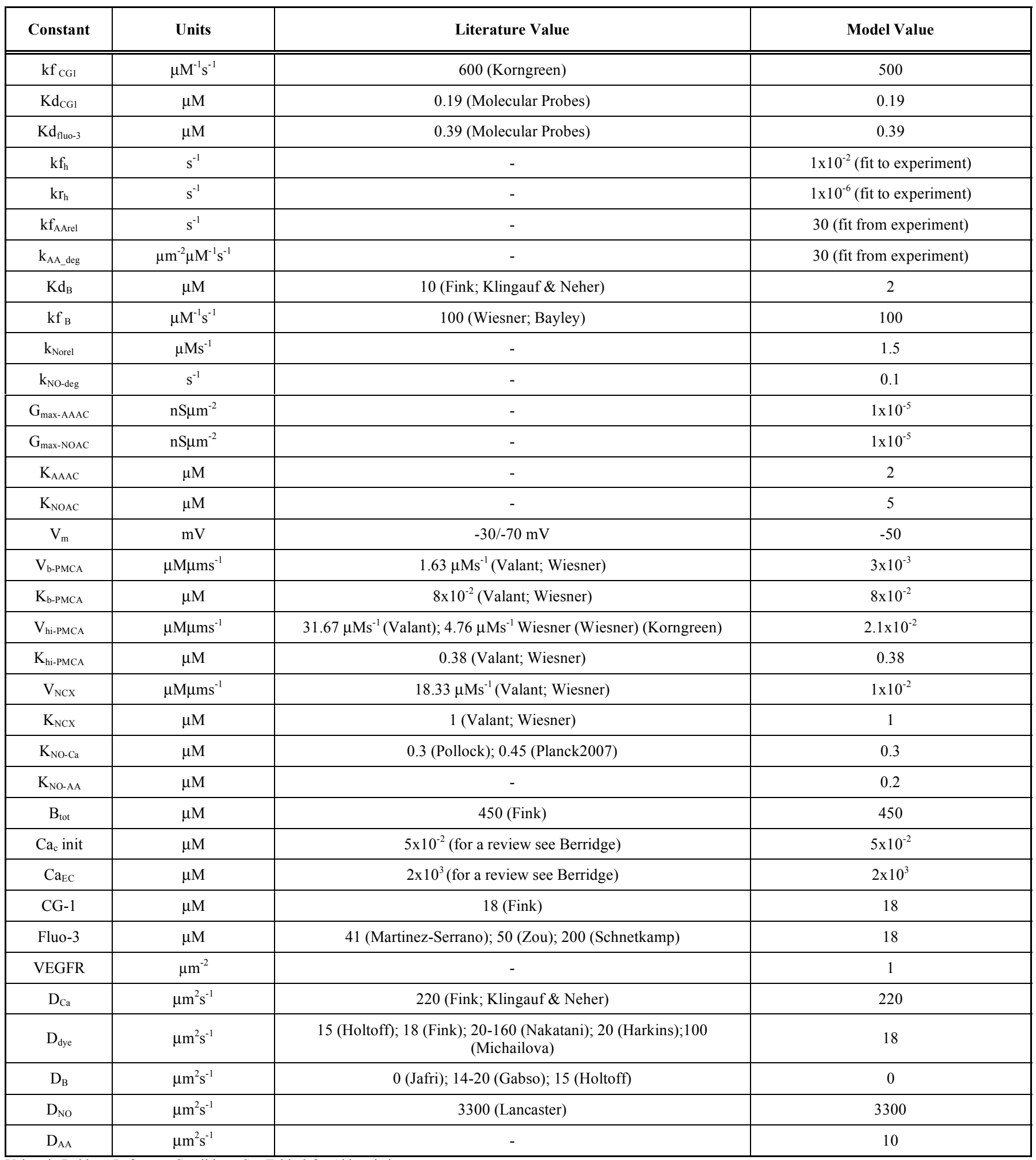


Table 3. Glossary for Model Constants of Table 2

\begin{tabular}{|c|c|}
\hline Constant & Definition \\
\hline $\mathrm{kf}_{\mathrm{CGl}}$ & On-rate constant for $\mathrm{Ca}$ binding to calcium green-1 \\
\hline $\mathrm{Kd}_{\mathrm{CG} 1}$ & Dissociation constant between $\mathrm{Ca}$ and calcium green-1 \\
\hline $\mathrm{Kd}_{\text {fluo-3 }}$ & Dissociation constant between $\mathrm{Ca}$ and fluo-3 \\
\hline $\mathrm{kf}_{\mathrm{h}}$ & On-rate constant for channel desensitization \\
\hline $\mathrm{kr}_{\mathrm{h}}$ & Off-rate constant for channel desensitization \\
\hline $\mathrm{kf}_{\text {AArel }}$ & On-rate constant for AA release \\
\hline $\mathrm{k}_{\mathrm{AA} \_ \text {deg }}$ & On-rate constant for AA degradation \\
\hline $\mathrm{Kd}_{\mathrm{B}}$ & Dissociation constant between endogenous buffer and $\mathrm{Ca}_{\mathrm{c}}$ \\
\hline $\mathrm{kf}_{\mathrm{B}}$ & On-rate constant for endogenous Ca buffering \\
\hline $\mathrm{k}_{\text {Norel }}$ & Maximal rate of NO release \\
\hline $\mathrm{k}_{\mathrm{NO}-\mathrm{deg}}$ & On-rate constant for NO degradation \\
\hline $\mathrm{G}_{\text {max-AAAC }}$ & Maximal conductance for AAAC \\
\hline $\mathrm{G}_{\max -\mathrm{NOAC}}$ & Maximal conductance for NOAC \\
\hline $\mathrm{K}_{\mathrm{AAAC}}$ & Half maximal AA concentration for AAAC activation \\
\hline $\mathrm{K}_{\mathrm{NOAC}}$ & Half maximal NO concentration for NOAC activation \\
\hline $\mathrm{V}_{\mathrm{m}}$ & Resting membrane potential \\
\hline $\mathrm{V}_{\mathrm{b}-\mathrm{PMCA}}$ & Maximal rate of pumping in the basal state \\
\hline $\mathrm{K}_{\mathrm{b}-\mathrm{PMCA}}$ & Michaelis-Menten constant for PMCA at basal state \\
\hline $\mathrm{V}_{\text {hi-PMCA }}$ & Maximal rate of pumping in the high capacity mode \\
\hline $\mathrm{K}_{\text {hi-PMCA }}$ & Michaelis-Menten constant for PMCA at high capacity mode \\
\hline $\mathrm{V}_{\mathrm{NCX}}$ & Maximal rate of extrusion by $\mathrm{Na}-\mathrm{Ca}$ exchanger \\
\hline $\mathrm{K}_{\mathrm{NCX}}$ & Michaelis-Menten constant for Na-Ca exchanger \\
\hline $\mathrm{K}_{\mathrm{NO}-\mathrm{Ca}}$ & Dissociation constant between $\mathrm{Ca}$ and eNOS \\
\hline $\mathrm{K}_{\mathrm{NO}-\mathrm{AA}}$ & Dissociation constant between AA and eNOS \\
\hline $\mathrm{B}_{\text {tot }}$ & Total endogenous buffer concentration \\
\hline $\mathrm{Ca}_{\mathrm{c}}$ init & Resting $\mathrm{Ca}_{\mathrm{c}}$ concentration \\
\hline $\mathrm{Ca}_{\mathrm{EC}}$ & Extracellular Ca concentration \\
\hline CG-1 & Total CG-1 concentration \\
\hline Fluo-3 & Total Fluo-3 concentration \\
\hline VEGFR & density of activated VEGFR molecules \\
\hline $\mathrm{D}_{\mathrm{Ca}}$ & Diffusion constant of cytosolic $\mathrm{Ca}$ \\
\hline $\mathrm{D}_{\text {dye }}$ & Diffusion constant of cytosolic calcium dye \\
\hline $\mathrm{D}_{\mathrm{B}}$ & Diffusion constant of cytosolic endogenous buffer \\
\hline $\mathrm{D}_{\mathrm{NO}}$ & Diffusion constant of NO \\
\hline $\mathrm{D}_{\mathrm{AA}}$ & Diffusion constant of AA \\
\hline
\end{tabular}

\section{Role of Cell Shape (Geometry)}

A first set of simulations was performed in a "control condition' (a set of 'standard' parameters, see Table 2) in order to evaluate the role of cell shape on proangiogenic AA- induced calcium signals. A cell with geometry $\mathbf{1}$ was chosen (with a large lamellipodium on the left side, see Fig. (1B) white circle, panels 1 and 3). For simulations in Figs. (4A and $\mathbf{E}$ ) and related graphs, we chose a plane on z-axis including the lamellipodium on the left side of the cell and 


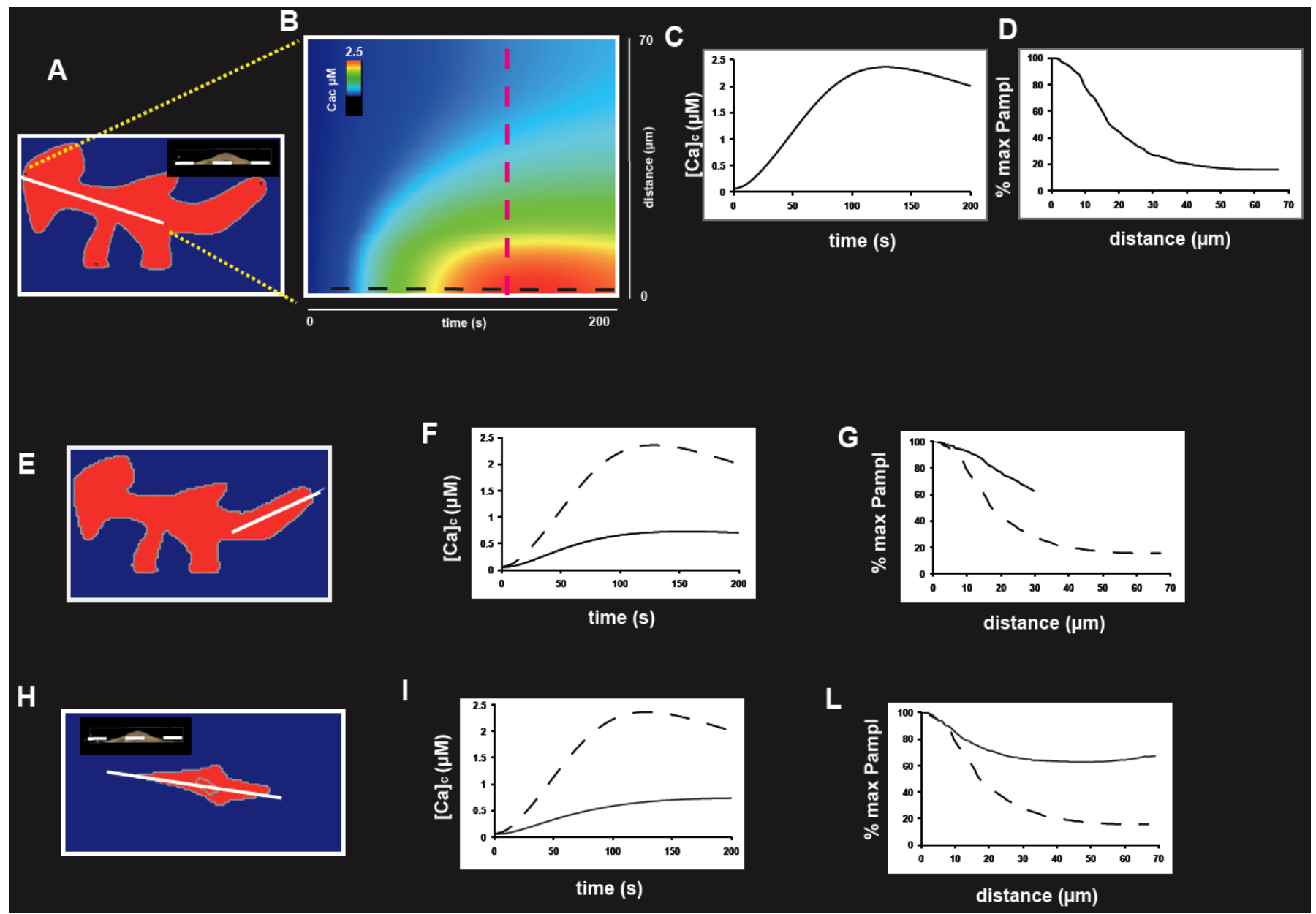

Fig. (4). Simulated $\mathrm{Ca}_{\mathrm{c}}$ responses in geometry 1 cells (with lamellipodia).

A-D. 'Reference condition'. A. z-plane chosen for simulation (corresponding to white dotted line in the inset). B. pls of simulations showing $\mathrm{Ca}_{\mathrm{c}}$ increase (in pseudocolor) during time ( $\mathrm{x}$ axis) along the white line in $\mathrm{A}$ (y axis). C. Time course of Ca increase in the subplasmamembrane region (orizontal black dotted line in $p l s$ in B; scale for calcium response amplitude: 0.045 to $2.5 \mu \mathrm{M}$ ). D. Relative calcium increase at the peak of the response $\left(\mathrm{P}_{\mathrm{ampl}}\right)$ along the red dotted line in B (130 s). E-G. The same for a line taken at the right extreme of the cell. Dotted lines in F and G are the same as in C and D ('reference condition'). H-L. The same as A-D across a z plane taken at $6 \mu \mathrm{m}$ from the bottom of the cell (white dotted line in the inset in $\mathrm{H}$ ).

thus approximately at $1 \mu \mathrm{m}$ from the bottom of the cell $(\mathrm{z}=0$, attachment to the substrate). In order to quantitatively evaluate the effects of lamellipodia on spatial $\mathrm{Ca}_{\mathrm{c}}$ increase propagation, we plotted, by a pseudo-line scanning $(p l s)$, the time course and $\mathrm{P}_{\mathrm{ampl}}$ decay of calcium response in the left lamellipodium: this was called 'reference' $p l s$ and used in all the following simulations. In a first set of simulations we excluded $\mathrm{I}_{\mathrm{AAAC}}$ and $\mathrm{I}_{\mathrm{NOAC}}$ from simulation in order to verify the stationary condition in 'resting' cells: as expected, according with experimental observations, no changes in $\mathrm{Ca}_{\mathrm{c}}$ levels were observed (not shown). When we included $\mathrm{I}_{\mathrm{AAAC}}$ and $\mathrm{I}_{\mathrm{NOAC}}$ in the simulation, a calcium response was observed (Figs. 4A-D). Firstly, reference was compared with pls from the opposite extreme of the cell (the right one, with significant higher thickness, as shown in Fig. 1B, blue circle in panels 1 and 3; Figs. 4E-G) and from a pls obtained choosing a $\mathrm{z}$ plane $5 \mu \mathrm{m}$ above the previous one $(6 \mu \mathrm{m}$ from the bottom on $\mathrm{z}$ axis).
The same type of analysis was performed on a cell with geometry 2 (Fig. 5).

In all the following analyses, we took some key indicators, including spatial decay of the peak of the response $\left(\mathrm{P}_{\mathrm{ampl}}\right)$ along the line selected and time to reach the peak $\left(t_{p}\right)$ in the subplasmamembrane region: all the values are shown in Table 4.

\section{Interference by Calcium-Sensitive Probes}

Different calcium-sensitive probes are commonly used to measure intracellular calcium responses. They differ for excitation and/or emission spectra and $K_{d}$ for calcium [31, $50,51]$. The introduction of these compounds inside the cell could lead to a perturbation of the physiological calcium buffering system, thus altering the measurement.

In order to test the effects of different calcium probes, we changed $\mathrm{K}_{\mathrm{d}}$ (according to the values given for calcium green- 


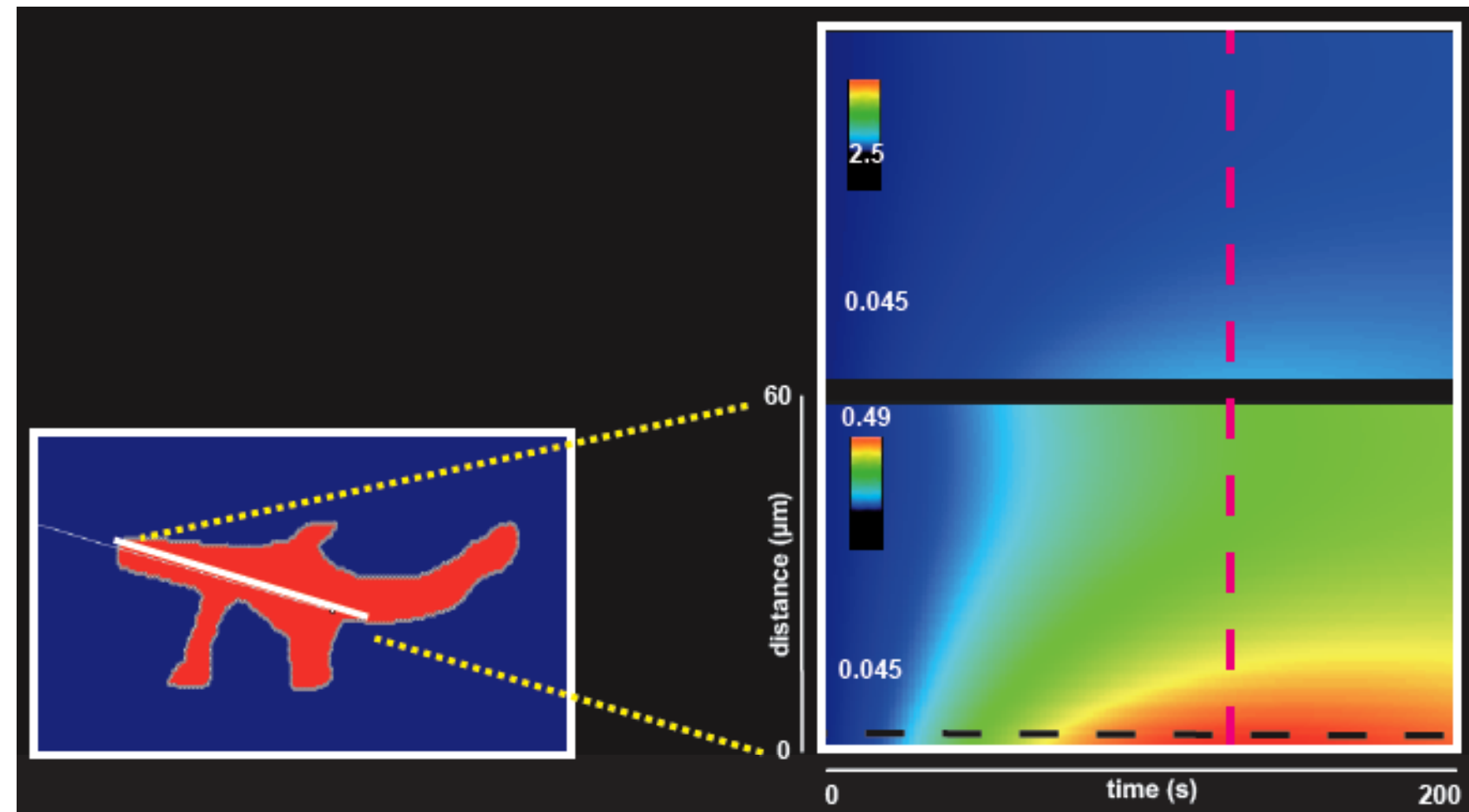

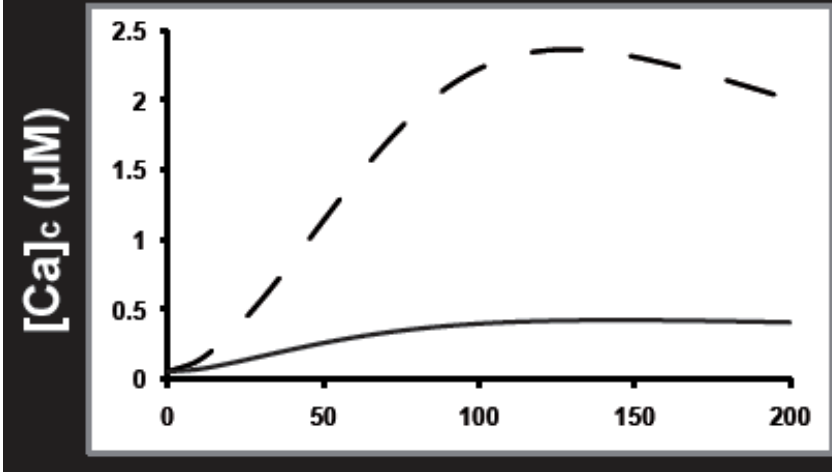

time (s)

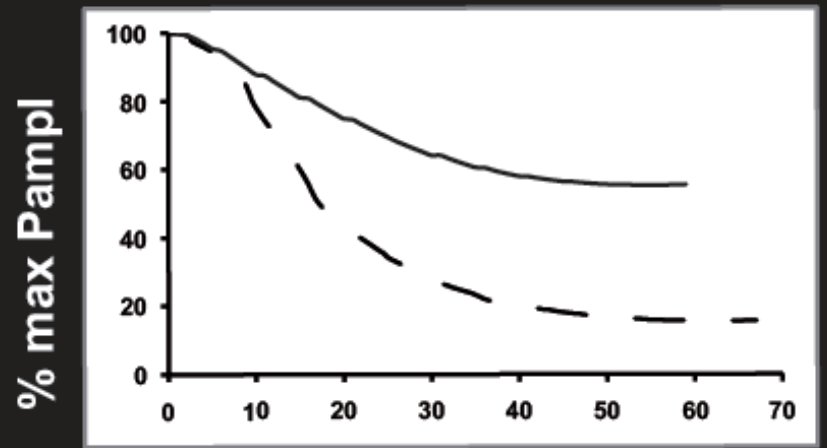

distance $(\mu \mathrm{m})$

C

D

Fig. (5). Simulated $\mathrm{Ca}_{\mathrm{c}}$ responses in geometry 2 cells (without lamellipodia).

The same as in Fig. (4), Fig. (5B) shows the same $p l s$ at two different scales for calcium increase: top is the same as in Fig. (4A) $(0.045$ to 2.5 $\mu \mathrm{M}$, for a direct comparison) and bottom an expanded scale $(0.045$ to $0.49 \mu \mathrm{M})$ to visualize the response.

1 and fluo-3, respectively 0.19 and $0.39 \mu \mathrm{M}$ ). Plots in Fig. (6) and Table 4 show the results of simulations.

Reduction of $\mathrm{K}_{\mathrm{d}}$ from $0.39 \mu \mathrm{M}$ to $0.19 \mu \mathrm{M}$ didn't affect neither the amplitude of the response nor the $\mathrm{P}_{\mathrm{ampl}}$ spatial decay.

In conditions in which dye is not present, the absolute $\mathrm{P}_{\mathrm{ampl}}$ is greater than control, as expected by the buffering effect of the dye: on the other hand, interestingly, the other parameters are not affected (Table 4). This is an important exclusive feature of the simulation, allowing testing the quantitative and qualitative effects of calcium-probes cell loading and eventually unmasking perturbations and artefacts due to the experimental procedure.

\section{Role of Spatial Restriction: Clusterization of Channels and Buffers}

Calcium diffusion inside the cell volume due to plasmamembrane calcium channels depends not only on the quantitative expression of channels and buffers but also by their specific targeting and distribution in specific cellular subcompartments.

Inhomogeneous channel distribution has been described in different cell types [23-25]. We analysed the effect of 
Table 4. Quantitative Results Obtained from Pseudo Line Scanning (pls) of Simulations

\begin{tabular}{|c|c|c|c|c|c|}
\hline Simulation & $\underset{\mathbf{P}_{\mathrm{ampl}}(\boldsymbol{M M})}{\operatorname{Max}}$ & $\begin{array}{l}\text { Time to peak } \\
\qquad\left(t_{p} ; s\right)\end{array}$ & $\begin{array}{c}\text { Distance at which } \\
\mathrm{P}_{\mathrm{ampl}}=50 \% \max \left(\mathrm{x}_{1 / 2} ;\right. \\
\mu \mathrm{m})\end{array}$ & $\begin{array}{l}\text { Minimum } P_{\text {ampl }} \\
\left(\% \max P_{\text {ampl }}\right)\end{array}$ & $\begin{array}{c}\text { Distance at which } \\
P_{\mathrm{ampl}} \text { is minimum } \\
(\mu \mathrm{m})\end{array}$ \\
\hline $\begin{array}{c}\text { Reference } \\
\text { (g1 cell; } \mathrm{z}=1 \mu \mathrm{m} ; \text { left lamellipodium) }\end{array}$ & 2.4 & 130 & 16 & 20 & 60 \\
\hline $\begin{array}{c}\text { Right protrusion } \\
\text { (g1 cell; } \mathrm{z}=1 \mu \mathrm{m} ; \text { right lamellipodium) }\end{array}$ & 0.72 & 130 & n.d. & 60 & 30 \\
\hline g1 cell; $z=6 \mu \mathrm{m}$; left lamellipodium) & 0.73 & 200 & n.d. & 60 & 40 \\
\hline $\mathrm{g} 2$ cell; $\mathrm{z}=1 \mu \mathrm{m}$ & 0.42 & 130 & & 55 & 40 \\
\hline Change of calcium probe $\left(\mathrm{K}_{\mathrm{d}}=0.19\right)$ & 2.4 & 130 & 16 & 20 & 60 \\
\hline No calcium probe & 2.8 & 130 & 16 & 20 & 60 \\
\hline Channel clusterization & 0.33 & 100 & 15 & 0 & 60 \\
\hline Buffer clusterization & 7.7 & 40 & 16 & 0 & 50 \\
\hline Double clusterization & 1.2 & 40 & 11 & 0 & 40 \\
\hline
\end{tabular}

A

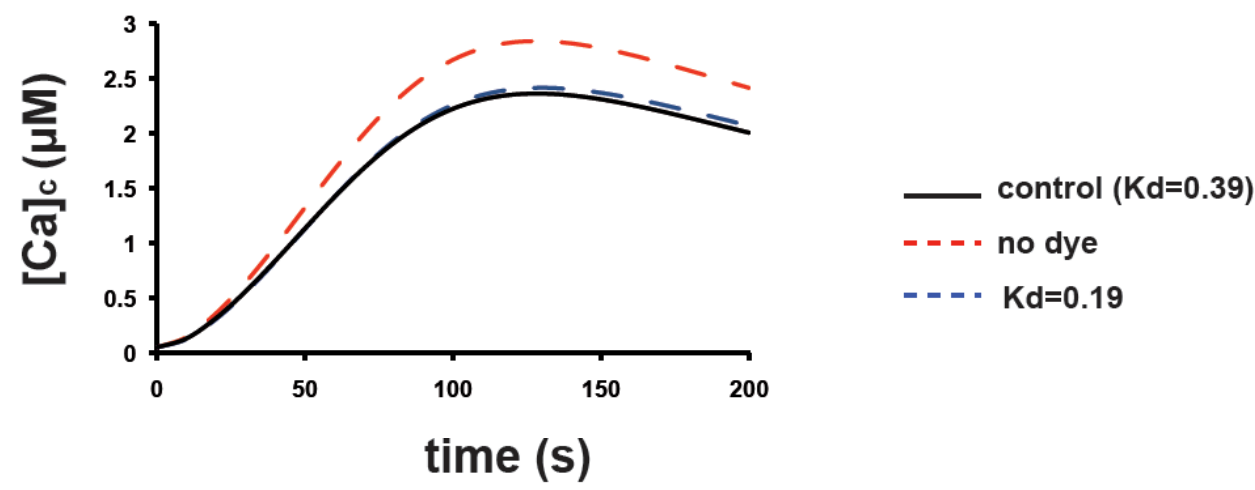

B

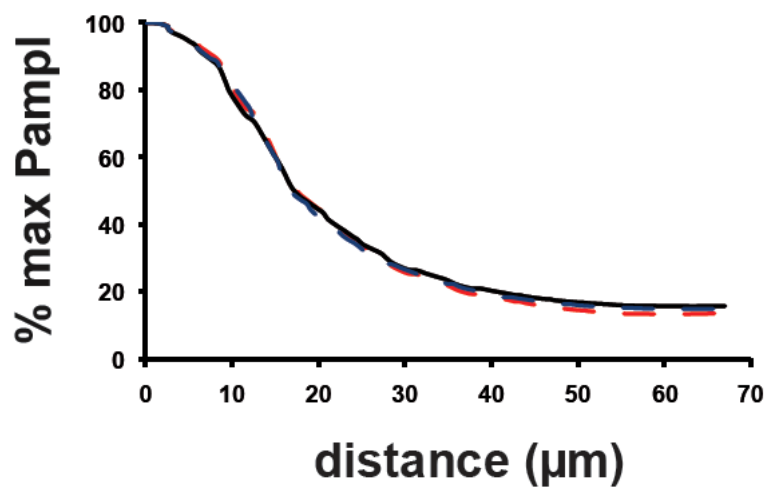

Fig. (6). Effects of calcium-sensitive probes.

Time course (A) and $\mathrm{P}_{\text {ampl }}$ decay $(\mathbf{B})$ obtained in control conditions (see Fig. (1A); calcium probe with $\mathrm{K}_{\mathrm{d}}=0.39 \mu \mathrm{M}$, black line), using a calcium probe with $\mathrm{K}_{\mathrm{d}}=0.19 \mu \mathrm{M}$ (blue dotted line) and without any probe (red dotted line).

channels compartmentalization by comparing cells without any molecular clusterization with cells in which channels are clusterized in the most peripheral regions with the same shape (Geometry 1).

Buffer clusterization has been set in the central region of the cell (containing the nucleus) where perinuclear mitochondria are more concentrated (as widely shown in literature in endothelial cells and confirmed here in BAECs by staining with orange mitotracker, (Fig. 7D)).

Fig. (7) shows the response of a cell in different conditions: with channel clusterization (Fig. 7A, panel 1-2), with buffer clusterization (in the central region of the cell, 


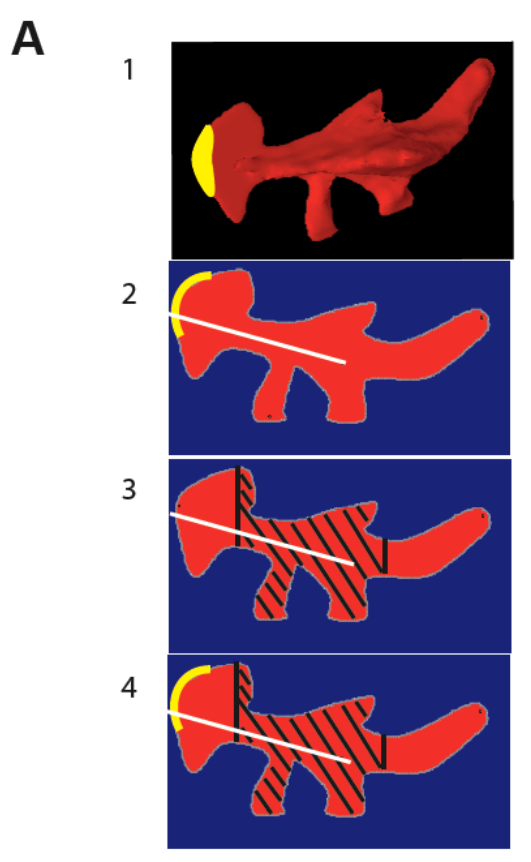

B
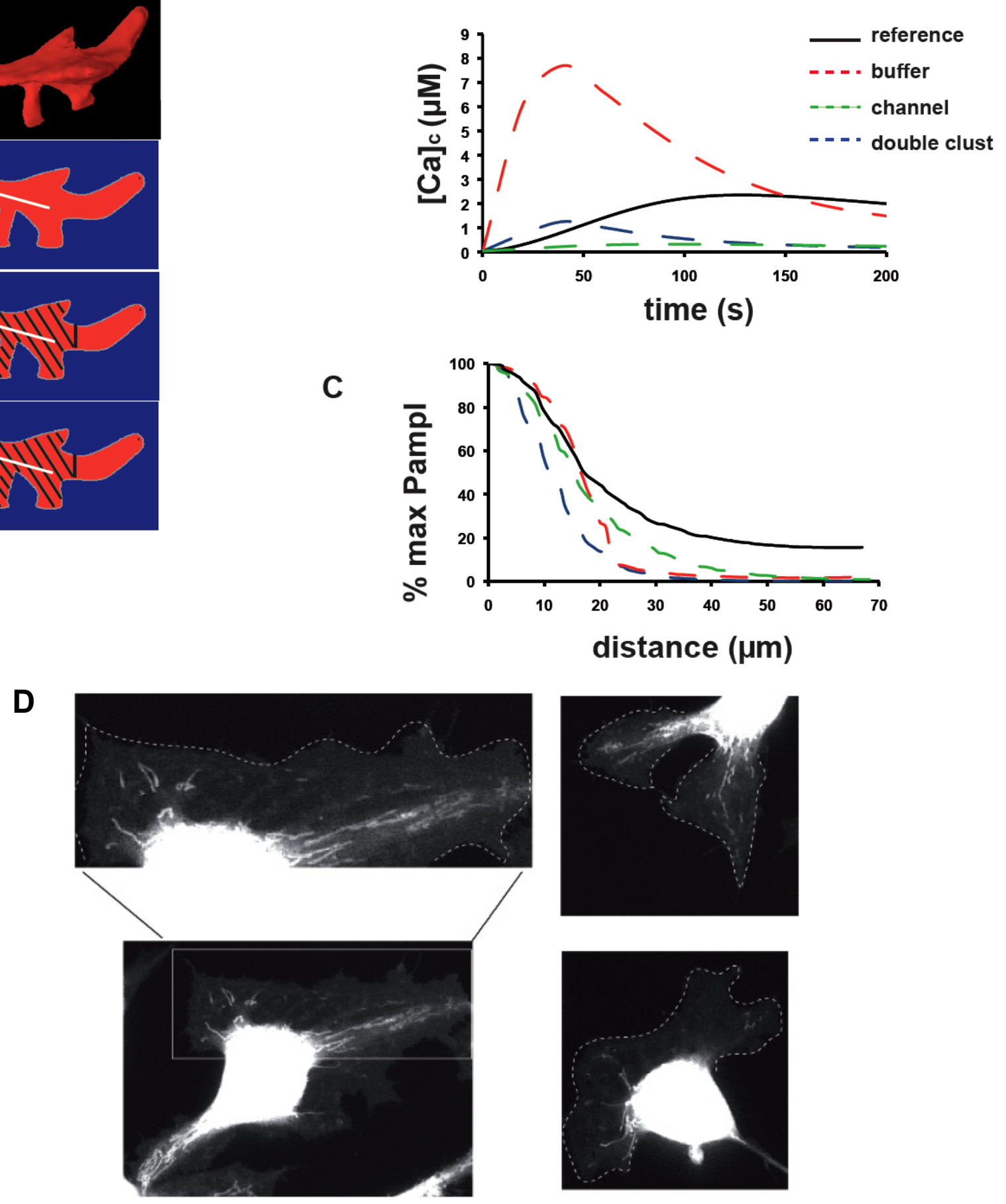

Fig. (7). Role of spatial restriction: clusterization of channels and endogenous buffer.

A. Scheme of the clusterization. Channels position is in yellow. Panels (from the top): 1. Channel clusterization (3D); 2. z plane taken at $1 \mu \mathrm{m}$ from the bottom of the cell; 3. Buffer clusterization in the same z-plane; 4. Double clusterization (channel and buffer). B, C. Time course and $\mathrm{P}_{\text {ampl }}$ decay of $\mathrm{Ca}_{\mathrm{c}}$ increase. D. Mitochondria distribution in lamellipodia of 3 cells detected with orange-mitotracker on confocal microscopy. Dashed lines are the boundaries of the cells.

including nucleus and perinuclear region, see Fig. (7A), panel 3) or with simultaneous clusterization of both the components (Fig. 7A, panel 4).

Figs. (7B, C) show the effect of clusterization on kinetics and spatial decay; the quantitative results are in Table 4.
As expected, buffer clusterization in the central region of the cell leads to a huge increase of absolute $P_{a m p l}$ in the peripheral regions, while channel clusterization evokes the opposite effect (Fig. 7B). Time to peak was highly reduced both by buffer clusterization and, even at lesser extent, by channel clusterization (Table 4). 
A

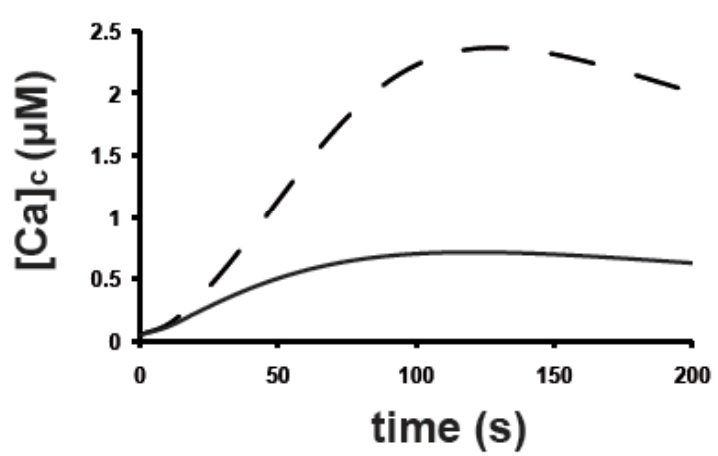

B

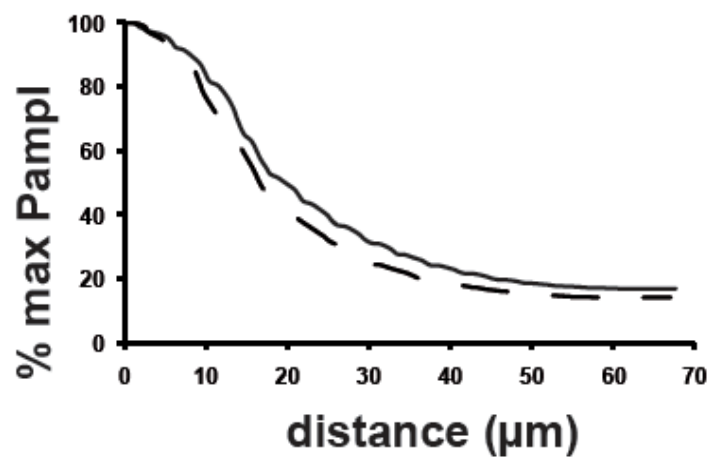

Fig. (8). A, B. Simulations of calcium increases in cells in which NO release was completely inhibited ( $\mathrm{J}_{\text {NOrel }}$ excluded from simulation). Dotted lines are control conditions.

Neither buffer nor channel clusterization did not significantly affect the distance at which $\mathrm{P}_{\mathrm{ampl}}=50 \% \max \left(\mathrm{x}_{1 / 2}\right.$; $\mu \mathrm{m})$ of spatial decay, while simultaneous clusterization of channels and buffers led to a significant reduction. Differently from control conditions, all these three clusterizations led to a complete abolishment of the response due to spatial decay (Fig. 7C and Table 4).

\section{Exclusion of Either AA or NO Release}

In order to reproduce the effects observed experimentally by interference with eNOS activity [17], we performed simulations excluding either AA or NO release (respectively $\mathrm{J}_{\mathrm{AArel}}$ and $\mathrm{J}_{\mathrm{NOrel}}$, equations 6 and 8) from simulation: as expected, blocking AA release completely abolished calcium signals (not shown), while the exclusion of eNOS activity from the simulation failed to exert any effect on time course and propagation of the response (Fig. 8 and Table 4 ).

\section{DISCUSSION}

In a previous paper we experimentally described the properties of peripheral calcium microdomains activated by proangiogenic factors (VEGF and bFGF) and arachidonic acid (AA) in bovine aortic endothelial cells: these events are involved in the control of normal and tumor-derived ECs proliferation and motility and are due to the opening of calcium-permeable channels in the plasmamembrane [17-19, 52]. We suggested that different mechanisms could be responsible for this spatial restriction, including channel clusterization, buffer distribution, and cell geometry.

A great number of details can be obtained experimentally, but the most commonly used techniques (patch clamp and calcium imaging with fluorescent probes) have many drawbacks and interfere with the physiology of the cell perturbing the intracellular processes in different ways [53, 54].

Even if a number of mathematical models for calcium signals have been published for different cell types, including ECs $[55,56]$, this work describes the first 3D modeling of proangiogenic calcium entry strictly based on experimental data. In particular, given the complex geometry of ECs, highly diverging from regular spherical shape, we designed our model on a $3 \mathrm{D}$ reconstruction of a real EC obtained by confocal microscopy: this should be considered mandatory for a realistic simulation.

The properties of proangiogenic calcium events (by VEGF, bFGF, AA and NO) allow us to design a relatively simple mathematical and graphical model thanks to the absence, in a precise range of AA stimulation (low micromolar levels, $<5 \mu \mathrm{M}$ ), of release from intracellular stores. We introduced biochemical quantitative parameters taken from the literature produced by our group and others: in many cases values are specifically referred to ECs, while in others, due to lack of experimental evidences in ECs, we assumed valued taken from other cell types [31, 42, 43].

For simulation of AA and NO release upon proangiogenic stimula, we started from experimental data concerning the signal transduction linking tyrosine kinase receptors (VEGFR, bFGFR) to AA and NO release in ECs $[16,57]$ : in particular, in our simplified model, AA release is triggered by VEGFR activation, while NO release is more complex, being regulated by cytosolic calcium and AA itself (see below). Time courses of AA and NO release, and their absolute concentrations, have been set in agreement with literature [37, 58].

The properties of proangiogenic calcium channels and relative currents are derived from the experimental data provided by our previous works $[17-19,35]$ : they have been obtained mainly from electrophysiological experiments (patch clamp in whole cell and single cell inside out configurations) and single cell fluorimetric measurements. In particular, AA-activated calcium current is typically non selective and shows a desensitization in the presence of the agonist (Table 1 and Fig. 3). Activation process is dependent on the concentration of AA (AA), physiologically released by different enzymes ([36], see model description). The mechanisms responsible for desensitization of AA-induced calcium current in the presence of the agonist are not known, even if in other cell types a phosphorylation/dephosphorylation balance has been suggested $[59,60]$ : the desensitization factor $\mathrm{h}$ is taken as $\mathrm{h}^{2}$ to fit the time course of the experimental current (Fig. 3). Peak amplitude and time to peak have been estimated from the amplitude of current density in whole cell patch clamp experiments: it has to be noted that both these parameters are quite variable from cell to cell (see Table 1) even in the same cell population. The 
relative permeabilities to cations have not been experimentally estimated: we fitted the value of $\mathrm{C}_{\max }$ in order to obtain calcium increase amplitude similar to that measured with quantiative dyes $[17,61]$.

In a set of simulations we tested the same experimental conditions in cells with or without thin lamellipodia: in our previous paper we observed that non confluent BAECs in monolayer have highly different dimensions and the peripheral processes (lamellipodia) are very thin compared to the central-nuclear region (difference in a range of one order of magnitude) [19]. The highly variable 3D geometry of the cells (shape, Surface/Volume ratio of peripheral processes and central-nuclear regions) could account, at least partially, for the preferential peripheral localization: the role of 3D cell structure has been discussed by several authors, mainly for agonists that activate calcium release from intracellular stores $[5,6,20,62]$.

The comparison of 2 different shapes/dimensions (Figs. 4 and 5) in our computational model clearly shows that, even in the absence of any channel or buffer clusterization, local $\mathrm{Ca}_{\mathrm{c}}$ events are clearly detectable in the more peripheral large and flat cell protrusions, near the attachment interface to the substrate: their amplitude decreases in the central/nuclear area. Other areas of the cells (more thick protrusions or regions $6 \mu \mathrm{m}$ above the attachment surface in $\mathrm{g} 1$ cells) or $\mathrm{g} 2$ cells, lacking thin protrusions, fail to display the same periphery-restricted response (Figs. 4, 5, Table 4). These observations could provide an additional explanation of the great heterogeneity of $\mathrm{Ca}_{\mathrm{c}}$ responses in the same cell population: not only calcium machinery expression can vary from cell to cell but also in cells expressing the same amount of channels, the response could change significantly in function of the geometry/shape. This is quite relevant during angiogenic process, in which ECs move, proliferate and reorganize in new vessels changing their shape.

As expected, calcium probes don't significantly affect spatial peak decay (Fig. 6, Table 4), allowing us to exclude that peripheral restriction of proangiogenic calcium signals previously described are artefacts due to calcium-sensitive dyes.

Another component to be considered is the spatial distribution of different cell components involved in calcium signaling and its effects. It is well known that eNOS, PLA tyrosine kinase receptors and calcium channels (including TRPs), all components of proangiogenic calcium signaling machinery, are clusterized in lipid rafts, caveolae and supermolecular complexes (or signallsomes) in the plasmamembrane $[12,23,25]$. Moreover the distribution of calcium buffers changes from cell to cell and contributes to the spatial restriction: in ECs, mitochondria form a perinuclear ring, protecting the nucleus from uncontrolled calcium increases in the cytosol, and a subplasmamembrane layer $[63,64]$. Accordingly, in the present model, the compartmentalization of buffers in the central-perinuclear region of g1 cell strongly decreases the time to peak of proangiogenicinduced calcium responses in the subplasmamembrane region of lamellipodia, while channel clusterization in the most peripheral region of lamellipodia in g1 cell leads to a huge reduction of peak amplitude: the combination of buffer and channel clusterization affects all the parameters (Fig. 7,
Table 4). It has to be noted that in all these conditions proangiogenic calcium signals fail to propagate to the nucleus, in agreement with experimental observations (19). When AA- and NO-activated channels will be identified, confocal fluorescence techniques at high spatial resolution will be needed to support the hypothesis of channel clusterization in the most peripheral regions of lamellipodia.

It has to be noted that the model contains a number of assumptions and it will be greatly improved by more constraints obtained mainly by biochemical quantitative measurements.

In particular, even because of the positive feedback of NO-dependent calcium entry on NOS activation, it is very hard to obtain experimental quantitative informations on the actual relative balance between activation of AAAC (a channel activated by $\mathrm{AA}$ independently on $\mathrm{NO}$ production) and recruitment of NOAC (a channel activated by NO previously released by AA action on NOS). Such a balance could depend on several unknwown parameters, including $\mathrm{K}_{\mathrm{AAAC}}, \mathrm{K}_{\mathrm{NOAC}}$ and $\mathrm{K}_{\mathrm{NO} A \mathrm{AA}}$. We need a more detailed knowledge on structural and functional properties of proangiogenic calcium channels and the discovery of the molecular mechanisms responsible for channel desensitization in endothelial cells will provide very useful informations to be added in the model.

This model is based on the hypothesis of two independent channels (AA- or NO-activated) but we cannot exclude neither the existence of channels co-modulated by AA and NO nor potential cross regulations between different channel types. Finally we need a more detailed quantitative description of the molecular machinery underlying AA and NO release following stimulation with proangiogenic peptides [65].

\section{ACKNOWLEDGEMENTS}

The work was supported by Italian Ministry of University and Research (MIUR), Ricerca Scientifica Applicata Sanita' Piemonte, and Fondazione CRT (Progetti Alfieri).

I would like to thank NRCAM and NCRR for Virtual Cell access.

\section{REFERENCES}

[1] Bootman MD, Lipp P, Berridge MJ. The organisation and functions of local $\mathrm{Ca}^{2+}$ signals. J Cell Sci 2001; 114(12): 2213-22.

[2] Rizzuto R, Pozzan T. Microdomains of intracellular $\mathrm{Ca}^{2+}$. Molecular determinants and functional consequences. Physiol Rev 2006; 86(1): 369-408.

[3] Rizzuto R, Duchen MR, Pozzan T. Flirting in little space: the ER/mitochondria $\mathrm{Ca}^{2+}$ liaison. Sci STKE 2004; 2004(215): re1.

[4] Macrez N, Mironneau J. Local $\mathrm{Ca}^{2+}$ signals in cellular signalling. Curr Mol Med 2004; 4(3): 263-75.

[5] Huser J, Blatter LA. Elementary events of agonist-induced $\mathrm{Ca}^{2+}$ release in vascular endothelial cells. Am J Physiol 1997; 273(5 Pt 1): C1775-82.

[6] Huser J, Holda JR, Kockskamper J, Blatter LA. Focal agonis stimulation results in spatially restricted $\mathrm{Ca}^{2+}$ release and capacitative $\mathrm{Ca}^{2+}$ entry in bovine vascular endothelial cells. J Physiol 1999; 514(Pt 1): 101-9.

[7] Olivos Ore L, Artalejo AR. Intracellular $\mathrm{Ca}^{2+}$ microdomaintriggered exocytosis in neuroendocrine cells. Trends Neurosci 2004; 27(3): 113-5. 
[8] Berridge MJ, Bootman MD, Roderick HL. Calcium signalling: dynamics, homeostasis and remodelling. Nat Rev Mol Cell Biol 2003; 4(7): 517-29.

[9] Marsault R, Murgia M, Pozzan T, Rizzuto R. Domains of high $\mathrm{Ca}^{2+}$ beneath the plasma membrane of living A7r5 cells. EMBO J 1997; 16(7): 1575-81.

[10] Young RC, Zhang P. Functional separation of deep cytoplasmic calcium from subplasmalemmal space calcium in cultured human uterine smooth muscle cells. Cell Calcium 2004; 36(1): 11-7.

[11] Sbaa E, Frerart F, Feron O. The double regulation of endothelial nitric oxide synthase by caveolae and caveolin: a paradox solved through the study of angiogenesis. Trends Cardiovasc Med 2005; 15(5): 157-62.

[12] Isshiki M, Mutoh A, Fujita T. Subcortical $\mathrm{Ca}^{2+}$ waves sneaking under the plasma membrane in endothelial cells. Circ Res 2004; 95(3): e11-21.

[13] Munaron L. Calcium signalling and control of cell proliferation by tyrosine kinase receptors (review). Int J Mol Med 2002; 10(6): 671-

[14] Munaron L, Antoniotti S, Lovisolo D. Intracellular calcium signals and control of cell proliferation: how many mechanisms? J Cell Mol Med 2004; 8(2): 161-8.

[15] Munaron L, Antoniotti S, Fiorio Pla A, Lovisolo D. Blocking $\mathrm{Ca}^{2+}$ entry: a way to control cell proliferation. Curr Med Chem 2004; 11(12): $1533-43$.

[16] Munaron L. Intracellular calcium, endothelial cells and angiogenesis. Recent Pat Anticancer Drug Discov 2006; 1(1): 10519 .

[17] Mottola A, Antoniotti S, Lovisolo D, Munaron L. Regulation of noncapacitative calcium entry by arachidonic acid and nitric oxide in endothelial cells. FASEB J 2005; 19(14): 2075-7.

[18] Fiorio Pla A, Munaron L. Calcium influx, arachidonic acid,and control of endothelial cell proliferation. Cell Calcium 2001; 30(4): $235-44$.

[19] Tomatis C, Fiorio Pla A, Munaron L. Cytosolic calcium microdomains by arachidonic acid and nitric oxide in endothelial cells. Cell Calcium 2007; 41(3): 261-9.

[20] Kraus M, Wolf B. Crosstalk between cellular morphology and calcium oscillation patterns. Insights from a stochastic computer model. Cell Calcium 1996; 19(6): 461-72.

[21] Wagner J, Li YX, Pearson J, Keizer J. Simulation of the fertilization $\mathrm{Ca}^{2+}$ wave in Xenopus laevis eggs. Biophys J 1998; 75(4): 2088-97.

[22] Albrecht MA, Colegrove SL, Friel DD. Differential regulation of ER $\mathrm{Ca}^{2+}$ uptake and release rates accounts for multiple modes of $\mathrm{Ca}^{2+}$-induced $\mathrm{Ca}^{2+}$ release. J Gen Physiol 2002; 119(3): 211-33.

[23] Isshiki M, Anderson RG. Calcium signal transduction from caveolae. Cell Calcium 1999; 26(5): 201-8.

[24] Isshiki M, Anderson RG. Function of caveolae in $\mathrm{Ca}^{2+}$ entry and $\mathrm{Ca}^{2+}$-dependent signal transduction. Traffic 2003; 4(11): 717-23.

[25] Ambudkar IS, Bandyopadhyay BC, Liu X, Lockwich TP, Paria B, Ong HL. Functional organization of TRPC-Ca ${ }^{2+}$ channels and regulation of calcium microdomains. Cell Calcium 2006; 40(5-6): 495-504.

[26] Kholodenko BN, Kolch W. Giving space to cell signaling. Cell 2008; 133(4): 566-7.

[27] Slepchenko BM, Schaff JC, Carson JH, Loew LM. Computational cell biology: spatiotemporal simulation of cellular events. Annu Rev Biophys Biomol Struct 2002; 31: 423-41.

[28] Slepchenko BM, Schaff JC, Macara I, Loew LM. Quantitative cell biology with the Virtual Cell. Trends Cell Biol 2003; 13(11): 5706.

[29] Moraru, II, Schaff JC, Slepchenko BM, Loew LM. The virtual cell: an integrated modeling environment for experimental and computational cell biology. Ann NY Acad Sci 2002; 971: 595-6.

[30] Sneyd J, Keizer J, Sanderson MJ. Mechanisms of calcium oscillations and waves: a quantitative analysis. FASEB J 1995; 9(14): 1463-72.

[31] Fink CC, Slepchenko B, Moraru, II, Watras J, Schaff JC, Loew LM. An image-based model of calcium waves in differentiated neuroblastoma cells. Biophys J 2000; 79(1): 163-83.

[32] Goto Y, Miura M, Iijima T. Extrusion mechanisms of intracellular $\mathrm{Ca}^{2+}$ in human aortic endothelial cells. Eur J Pharmacol 1996; 314(1-2): 185-92.

[33] Moccia F, Berra-Romani R, Baruffi S, Spaggiari S, Signorelli S, Castelli $\mathrm{L}$, et al. $\mathrm{Ca}^{2+}$ uptake by the endoplasmic reticulum $\mathrm{Ca}^{2+}$ -
ATPase in rat microvascular endothelial cells. Biochem J 2002; 364(Pt 1): 235-44.

[34] Coatesworth W, Bolsover S. Calcium signal transmission in chick sensory neurones is diffusion based. Cell Calcium 2008; 43(3): 236-49.

[35] Munaron L, Fiorio Pla A. Calcium influx induced by activation of tyrosine kinase receptors in cultured bovine aortic endothelial cells. J Cell Physiol 2000; 185(3): 454-63.

[36] Khanapure SP, Garvey DS, Janero DR, Letts LG. Eicosanoids in inflammation: biosynthesis, pharmacology, and therapeutic frontiers. Curr Top Med Chem 2007; 7(3): 311-40.

[37] Blatter LA, Taha Z, Mesaros S, Shacklock PS, Wier WG, Malinski T. Simultaneous measurements of $\mathrm{Ca}^{2+}$ and nitric oxide in bradykinin-stimulated vascular endothelial cells. Circ Res 1995 76(5): 922-4.

[38] Pollock JS, Forstermann U, Mitchell JA, et al. Purification and characterization of particulate endothelium-derived relaxing factor synthase from cultured and native bovine aortic endothelial cells. Proc Natl Acad Sci USA 1991; 88(23): 10480-4.

[39] Plank MJ, Wall DJ, David T. The role of endothelial calcium and nitric oxide in the localisation of atherosclerosis. Math Biosci 2007; 207(1): 26-39.

[40] Pacher P, Beckman JS, Liaudet L. Nitric oxide and peroxynitrite in health and disease. Physiol Rev 2007; 87(1): 315-424.

[41] Valant PA, Adjei PN, Haynes DH. Rapid $\mathrm{Ca}^{2+}$ extrusion via the $\mathrm{Na}^{+} / \mathrm{Ca}^{2+}$ exchanger of the human platelet. J Membr Biol 1992; 130(1): 63-82.

[42] Plank MJ, Wall DJ, David T. Atherosclerosis and calcium signalling in endothelial cells. Prog Biophys Mol Biol 2006; 91(3): 287-313.

[43] Wiesner TF, Berk BC, Nerem RM. A mathematical model of cytosolic calcium dynamics in human umbilical vein endothelial cells. Am J Physiol 1996; 270 (5 Pt 1): C1556-69.

[44] Jafri MS, Vajda S, Pasik P, Gillo B. A membrane model for cytosolic calcium oscillations. A study using Xenopus oocytes. Biophys J 1992; 63(1): 235-46.

[45] Jafri MS, Keizer J. On the roles of $\mathrm{Ca}^{2+}$ diffusion, $\mathrm{Ca}^{2+}$ buffers, and the endoplasmic reticulum in IP3-induced $\mathrm{Ca}^{2+}$ waves. Biophys J 1995; 69(5): 2139-53.

[46] Klingauf J, Neher E. Modeling buffered $\mathrm{Ca}^{2+}$ diffusion near the membrane: implications for secretion in neuroendocrine cells. Biophys J 1997; 72(2 Pt 1): 674-90.

[47] Bayley P, Ahlstrom P, Martin SR, Forsen S. The kinetics of calcium binding to calmodulin: Quin 2 and ANS stopped-flow fluorescence studies. Biochem Biophys Res Commun 1984; 120(1): 185-91.

[48] Fink C, Morgan F, Loew LM. Intracellular fluorescent probe concentrations by confocal microscopy. Biophys J 1998; 75(4) $1648-58$

[49] Korngreen A, Gold'shtein V, Priel Z. A realistic model of biphasic calcium transients in electrically nonexcitable cells. Biophys $\mathrm{J}$ 1997; 73(2): 659-73.

[50] Michailova A, DelPrincipe F, Egger M, Niggli E. Spatiotemporal features of $\mathrm{Ca}^{2+}$ buffering and diffusion in atrial cardiac myocytes with inhibited sarcoplasmic reticulum. Biophys J 2002; 83(6): 3134-51.

[51] Nakatani K, Chen C, Koutalos Y. Calcium diffusion coefficient in rod photoreceptor outer segments. Biophys J 2002; 82(2): 728-39.

[52] Fiorio Pla A, Grange C, Antoniotti S, et al. Arachidonic acidinduced $\mathrm{Ca}^{2+}$ entry is involved in early steps of tumor angiogenesis. Mol Cancer Res 2008; 6(4):535-45.

[53] Thomas D, Tovey SC, Collins TJ, Bootman MD, Berridge MJ, Lipp P. A comparison of fluorescent $\mathrm{Ca}^{2+}$ indicator properties and their use in measuring elementary and global $\mathrm{Ca}^{2+}$ signals. Cell Calcium 2000; 28(4): 213-23.

[54] Sakmann B, Neher E. Patch clamp techniques for studying ionic channels in excitable membranes. Annu Rev Physiol 1984; 46 455-72.

[55] Hong D, Jaron D, Buerk DG, Barbee KA. Transport-dependent calcium signaling in spatially segregated cellular caveolar domains. Am J Physiol Cell Physiol 2008; 294(3): C856-66.

[56] Hunding A, Ipsen M. Simulation of waves in calcium models with 3D spherical geometry. Math Biosci 2003; 182(1): 45-66.

[57] Munaron L, Tomatis C, Fiorio Pla A. The secret marriage between calcium and tumor angiogenesis. Technol Cancer Res Treat 2008; 7(4): 335-9. 
[58] Kimura H, Esumi H. Reciprocal regulation between nitric oxide and vascular endothelial growth factor in angiogenesis. Acta Biochim Pol 2003; 50(1): 49-59.

[59] Shuttleworth TJ, Thompson JL, Mignen O. ARC channels: a novel pathway for receptor-activated calcium entry. Physiology (Bethesda) 2004; 19: 355-61.

[60] Mignen O, Thompson JL, Shuttleworth TJ. Arachidonate-regulated $\mathrm{Ca}^{2+}$-selective (ARC) channel activity is modulated by phosphorylation and involves an A-kinase anchoring protein. J Physiol 2005; 567(Pt 3): 787-98.

[61] Munaron L, Antoniotti S, Distasi C, Lovisolo D. Arachidonic acid mediates calcium influx induced by basic fibroblast growth factor in Balb-c 3T3 fibroblasts. Cell Calcium 1997; 22(3): 179-88.
[62] Aird WC. Phenotypic heterogeneity of the endothelium: I. Structure, function, and mechanisms. Circ Res 2007; 100(2): 15873.

[63] Collins TJ, Berridge MJ, Lipp P, Bootman MD. Mitochondria are morphologically and functionally heterogeneous within cells. EMBO J 2002; 21(7): 1616-27.

[64] Malli R, Frieden M, Osibow K, Graier WF. Mitochondria efficiently buffer subplasmalemmal $\mathrm{Ca}^{2+}$ elevation during agonist stimulation. J Biol Chem 2003; 278(12): 10807-15.

[65] Antoniotti S, Fiorio Pla A, Pregnolato S, Mottola A, Lovisolo D, Munaron L. Control of endothelial cell proliferation by calcium influx and arachidonic acid metabolism: a pharmacological approach. J Cell Physiol 2003; 197(3): 370-8.

Received: March 05, 2009

Revised: May 20, 2009

Accepted: June 10, 2009

(C) Luca Munaron; Licensee Bentham Open.

This is an open access article licensed under the terms of the Creative Commons Attribution Non-Commercial License (http://creativecommons.org/licenses/by$\mathrm{nc} / 3.0 /$ ), which permits unrestricted, non-commercial use, distribution and reproduction in any medium, provided the work is properly cited. 